\title{
FAKTOR-FAKTOR YANG MEMPENGARUHI JUMLAH PEMBIAYAAN SYARIAH MELALUI PROGRAM RUMAH PEMBIAYAAN PERTANIAN
}

\section{FACTORS AFFECTING THE AMOUNT OF SHARIA FINANCING THROUGH AGRICULTURAL FINANCING HOUSE PROGRAM}

\author{
Deby Diana*, Tuti Karyani \\ Program Studi Agribisnis Fakultas Pertanian Universitas Padjadjaran \\ Jl. Raya Bandung-Sumedang Km. 21, Jatinangor, Kabupaten Sumedang, Jawa Barat \\ *E-mail: debydiana97@gmail.com \\ (Diterima 08-08-2020; Disetujui 07-09-2020)
}

\begin{abstract}
ABSTRAK
Di Indonesia sektor pertanian merupakan sektor yang dinilai memiliki risiko yang cukup tinggi, sehingga minat lembaga pembiayaan kurang untuk mendanai sektor ini. Alternatif yang perlu dilakukan untuk menjangkau permodalan dalam sektor pertanian adalah dengan adanya lembaga permodalan yang mampu menawarkan sistem yang mudah dan tidak memberatkan para petani. Hal tersebut diterapkan melalui program Rumah Pembiayaan Pertanian (RPP) yang diharapkan dapat membantu petani dalam permodalan melalui pembiayaan syariah. Penelitian ini bertujuan untuk menganalisis faktor-faktor apa saja yang dapat mempengaruhi jumlah pengambilan pembiayaan syariah melalui program RPP. Desain penelitian yang digunakan adalah kuantitatif dengan metode sensus. Penelitian ini menggunakan metode analisis regresi linear berganda. Hasil penelitian menunjukkan bahwa faktor yang berbanding lurus mempengaruhi jumlah pembiayaan syariah melalui RPP adalah tanggungan keluarga, lama menjadi nasabah, pengalaman usaha, frekuensi pembiayaan dan skala usaha. Faktor yang berbanding terbalik mempengaruhi jumlah pengambilan pembiayaan melalui RPP adalah pendapatan usaha dan tahun pendidikan.
\end{abstract}

Kata Kunci: Pembiayaan Syariah, Rumah Pembiayaan Pertanian

\begin{abstract}
In Indonesia the agricultural sector is a sector that is considered to have a high enough risk, so the interest of financial institutions is less to fund this sector. An alternative that needs to be done to reach capital in the agricultural sector is by having a capital institution that is able to offer a system that is easy and not burdensome for farmers. This is implemented through the RPP program which is expected to help farmers in capital through Islamic financing. The purpose of this study is to analyze the effectiveness of Islamic financial institutions and see what are the factors that can influence the amount of sharia financing taking through the RPP program. This research design uses is quantitative with the census method. This study uses multiple linier regression analysis methods. The results showed that the factors that directly affect the amount od Islamic financing through the RPP are family dependents, length of time being customers, business experience, frequency of financing and business scale. Factors that inversely affect the amount of funding taken through the RPP are business income and years of education.
\end{abstract}

Keywords: Sharia Financing, Agricultural Financing House 


\section{FAKTOR-FAKTOR YANG MEMPENGARUHI JUMLAH PEMBIAYAAN SYARIAH \\ MELALUI PROGRAM RUMAH PEMBIAYAAN PERTANIAN \\ Deby Diana, Tuti Karyani}

\section{PENDAHULUAN}

Di Indonesia sektor pertanian mempunyai peran strategis baik bagi masyarakat maupun pemerintah dalam pembangunan nasional. Menurut Roziq et al (2014), dalam pembangunan nasional bentuk peran tersebut berupa kontribusi terhadap Produk Domestik Bruto (PDB), penyerap tenaga kerja, bahan baku usaha kecil, sumber devisa, sumber gizi dan bahan pangan serta penggerak sektor ekonomi rill lainnya. Penyerapan tenaga kerja terbesar di Indonesia dihasilkan oleh sektor pertanian yang mampu menyerap sebanyak 35,70 juta orang atau sekitar 28,79\% serta kontribusi Produk Domestik Bruto (PDB) yang diberikan untuk negara sebesar 12,81\% (BPS, 2019).

Komoditi yang dihasilkan oleh sektor pertanian mempunyai sifat voluminous, bulky, dan tergantung kepada kondisi alam seperti iklim, cuaca dan lahan sehingga dinilai memiliki risiko yang cukup tinggi (Anjani, 2013). Permasalahan yang dihadapi oleh para pelaku usaha yang bergerak di sektor pertanian selain memiliki risiko yang cukup tinggi, ternyata juga memiliki keterbatasan akses permodalan untuk meningkatkan skala usahanya. Menurut Aries (2010), sektor pertanian yang memiliki karakteristik mengandung banyak risiko serta memiliki grace periode dimana dalam bidang pertanian terutama on-farm terdapat masa rentang antara masa tanam dengan masa panen, sehingga menyebabkan kurangnya minat lembaga keuangan untuk mendanai sektor ini. Berdasarkan karakteristik tersebut perlu dicari alternatif sistem pembiayaan yang cocok dengan karakteristik pertanian.

Di Indonesia terdapat dua lembaga keuangan, yaitu lembaga keuangan syariah dan lembaga keuangan konvensional. Hal ini diatur dalam pasal 1 ayat 1 UU No. 7 Tahun 1992 tentang Perbankan. Perbedaan dari kedua lembaga ini dapat dilihat dari sistem keuntungan yang mereka terapkan. Pengoperasian lembaga keuangan syariah disesuaikan dengan prinsip bagi hasil yang disesuaikan dengan prinsip syariah Islam, sedangkan lembaga keuangan konvensional menerapkan sistem bunga dalam pengoperasiannya. Menurut Barus (2009), pembiayaan yang menerapkan bagi hasil dalam pengoperasiannya lebih adil, karena kegiatan pembiayaan yang dilakukan melihat bagaimana kondisi keberhasilan nasabah yang diberikan pembiayaan oleh lembaga keuangan tersebut, sedangkan lembaga yang 
menerapkan sistem bunga dalam pengoperasiannya lebih bersifat eksploitasi karena tidak melihat kondisi keuangan dari nasabah.

Lembaga keuangan syariah berpeluang besar dan bisa menjadi salah satu solusi bagi para petani dalam pengalokasian pembiayaan pertaniannya. Hal tersebut dikarenakan sektor pertanian memiliki risiko tinggi, sehingga dibutuhkan pembiayaan yang lebih mudah dan fleksibel dalam hal pembagian keuntungan dan kerugian dalam berusaha. Lembaga keuangan yang memfasilitasi masyarakat kalangan bawah untuk memperoleh permodalan dengan memakai pola pembiayaan syariah adalah Lembaga Keuangan Mikro Syariah (LKMS). Menurut Robinson (2000), berikut alasan mengapa LKMS berguna untuk masyarakat kalangan bawah. Pertama, pembiayaan yang ditawarkan kepada masyarakat tergolong mudah untuk digunakan dalam berusaha. Kedua, lembaga keuangan memberikan fasilitas untuk menabung, sehingga masyarakat dapat menginvestasikan uangnya dalam jangka panjang. Ketiga, LKMS dapat melayani usaha yang bersifat unbankable, sehingga dapat menimbulkan kepercayaan diri dari masyarakat untuk terus meningkatkan skala usaha mereka. Lembaga Keuangan Mikro Syariah dapat berbentuk bank maupun non-bank. Bank Pembiayaan Rakyat Syariah (BPRS) termasuk salah satu contoh LKMS yang berbentuk bank, sedangkan Kelompok Swadaya Masyarakat (KSM) termasuk contoh LKMS yang berbentuk non-bank.

Pada prinsipnya terdapat tujuh jenis akad yang diterapkan pada mekanisme pembiayaan sistem syariah. Berdasarkan data OJK Oktober 2019, dalam mengeluarkan pembiayaan, rata-rata penggunaan akad Murabahah lebih banyak digunakan pada lembaga keuangan syariah, di bandingkan dengan akad lainya (Tabel 1).

Tabel 1. Jumlah Pembiayaan Berdasarkan Jenis Akad

\begin{tabular}{ccc}
\hline Jenis Akad & $\begin{array}{c}\text { Jumlah } \\
\text { (Miliar) }\end{array}$ & Persentase \\
\hline Mudharabah & 13,409 & 3,88 \\
Musyarakah & 149,653 & 43,34 \\
Murabahah & 159,410 & 46,17 \\
Qardh & 10,315 & 2,99 \\
Istishna & 1,988 & 0,58 \\
Ijarah & 10,508 & 3,04 \\
Salam & 0 & 0 \\
\hline
\end{tabular}

Sumber: Statistik Perbankan Syariah Oktober 2019 (OJK, 2019)

Dilihat dari Tabel 1 penggunakan akad Salam belum tersentuh oleh lembaga keuangan syariah di Indonesia, padahal akad Salam dapat dijadikan solusi dalam sektor pertanian. Menurut Widiana (2017), akad salam atau disebut juga akad beli tangguh adalah akad 
pembiayaan suatu barang dengan cara pemesanan dan pembayaran harga yang dilakukan terlebih dahulu dengan syarat tertentu yang disepakati. Hal ini sangat sesuai dengan kondisi petani di Indonesia yang rata-rata hanya memiliki modal kecil dan baru akan memiliki uang jika masa panen sudah tiba.

LKMS yang dapat dijadikan solusi untuk pembiayaan pertanian adalah Kelompok Swadaya MasyarakatKelompok Usaha Bersama Jaya Amanah yang selanjutnya disingkat KSM-KUB Jaya Amanah. KSM-KUB Jaya Amanah bekerja sama dengan salah satu lembaga keuangan resmi dalam pembiayaan syariah yaitu Lembaga Amil Zakat (LAZ) Al-Azhar dalam memberikan bantuan modal untuk petani-petani di Kecamatan Pacet. Dana yang digulirkan oleh LAZ Al-Azhar berasal dari dana sosial dari CIMB Niaga Syariah. KSM-KUB Jaya Amanah sudah berdiri sejak tahun 2014 yang awal mulanya berbentuk Kelompok Usaha Bersama dengan tujuan untuk pemberdayaan santri melalui sektor peternakan. KSM-KUB Jaya Amanah terus melakukan perkembangan hingga saat ini sudah merambat ke sektor pertanian. Khusus sektor pertanian KSMKUB Jaya Amanah menerapkan akad salam pada program pemberdayaan melalui Rumah Pembiayaan Pertanian untuk memberikan bantuan modal kepada petani. Alasan KSM-KUB Jaya Amanah memberikan bantuan modal karena awalnya banyak petani-petani yang masih menerapkan sistem ijon dan sistem pinjaman rentenir di kecamatan Pacet. Terdapat tiga desa dimana sistem ijon dan sistem pinjaman rentenir tergolong tinggi yaitu Desa Mek,arjaya, Desa Cinanggela dan Desa Pangauban. Sistem ijon dan sistem pinjaman rentenir yang diterapkan oleh petani-petani tergolong tinggi, karena jauhnya akses permodalan di desa tersebut sehingga menyebabkan petani harus bergantung kepada tengkulak. Melalui program RPP yang dijalankan oleh KSM-KUB Jaya Amanah mulai membantu meringankan permasalahan yang dialami oleh petani di Desa Mekarjaya.

KSM-KUB Jaya Amanah merupakan KSM yang memiliki jumlah anggota terbesar dari $26 \mathrm{KSM}$ yang diberi bantuan modal oleh LAZ Al-Azhar yaitu 125 orang, dengan rincian 54 petani, 50 peternakan, dan 21 UMKM. KSM-KUB Jaya Amanah sebagai lembaga binaan dari LAZ Al-Azhar sudah memiliki tiga program yaitu Rumah Pembiayaan Pertanian (RPP), pembiayaan peternakan dan UMKM. Rumah Pembiayaan 
Pertanian merupakan program unggulan yang diinisiasikan oleh LAZ Al-Azhar dalam rangka membantu permodalan petani melalui KSM-KUB Jaya Amanah.

Rumah Pembiayaan Pertanian sebagai program yang telah membantu petani dalam menangani permasalahan permodalan dan program unggulan yang diinisiasikan oleh LAZ Al-Azhar, tentu dapat dijadikan pilihan sebagai media pembiayaan untuk pemenuhan permodalan bagi petani. Ketertarikan petani untuk meminjam modal melalui Rumah Pembiayaan Pertanian tentu dipengaruhi oleh beberapa faktor. Oleh karena itu, perlu diteliti faktor-faktor apa saja yang mempengaruhi jumlah pengambilan pembiayaan melalui Rumah Pembiayaan Pertanian.

\section{METODE PENELITIAN}

Penelitian ini berlokasi di Rumah Pembiayaan Pertanian KSM-KUB Jaya Amanah, Kampung Paninggaran, Desa Mekarjaya, Kecamatan Pacet, Kabupaten Bandung, Jawa Barat pada bulan November 2019 - Februari 2020. Pemilihan lokasi penelitian dilakukan secara secara purposive (sengaja) dengan mempertimbangkan bahwa Rumah Pembiayaan Pertanian menawarkan pembiayaan untuk sektor pertanian.
Desain penelitian yang digunakan adalah penelitian kuantitatif dengan metode penelitian sensus. Menurut Arikunto (2006), apabila jumlah suatu populasi kurang dari 100, maka lebih baik semuanya dijadikan sebagai responden. Maka, dalam penelitian ini yang menjadi populasi adalah seluruh anggota yang tergabung dalam Rumah Pembiayaan Pertanian yaitu sebanyak 54 orang. Teknik pengumpulan data menggunakan teknik observasi, wawancara, dokumentasi dan studi pustaka.

Analisis faktor-faktor yang mempengaruhi jumlah pengambilan pembiayaan melalui RPP menggunakan model analisis regresi linier berganda. Variabel dependen adalah jumlah pembiayaan yang disalurkan, dan variabel independen adalah tanggungan keluarga (X1), lama menjadi nasabah (X2), pengalaman usaha (X3), pendapatan usaha (X4), frekuensi pembiayaan (X5), skala usaha (X6), dan tahun pendidikan (X7).

Persamaan mengenai faktor-faktor yang diduga mempengaruhi pembiayaan syariah sebagai berikut:

$$
\begin{aligned}
\mathrm{Y}= & \alpha_{0}+\alpha_{1} \mathrm{X}_{1}+\alpha_{2} \mathrm{X}_{2}+\alpha_{3} \mathrm{X}_{3}+\alpha_{4} \mathrm{X}_{4}+ \\
& \alpha_{5} \mathrm{X}_{5}+\alpha_{6} \mathrm{X}_{6}+\alpha_{7} \mathrm{X}_{7}+\mathrm{e}
\end{aligned}
$$




\section{FAKTOR-FAKTOR YANG MEMPENGARUHI JUMLAH PEMBIAYAAN SYARIAH \\ MELALUI PROGRAM RUMAH PEMBIAYAAN PERTANIAN \\ Deby Diana, Tuti Karyani}

Dimana:

$\mathrm{Y}=$ jumlah pembiayaan yang disalurkan (rupiah)

$\mathrm{X}_{1}=$ tanggungan keluarga (orang)

$\mathrm{X}_{2}=$ lama menjadi nasabah (bulan)

$\mathrm{X}_{3}=$ pengalaman usaha (tahun)

$\mathrm{X}_{4}=$ pendapatan usaha $(\mathrm{Rp} / \mathrm{musim})$

$\mathrm{X}_{5}=$ frekuensi pembiayaan (kali)

$\mathrm{X}_{6}=$ skala usaha (rupiah)

$\mathrm{X}_{7}=$ tahun pendidikan (tahun)

$\alpha_{0}, \alpha_{1}, \alpha_{2}, \alpha_{3}, \alpha_{4}, \alpha_{5}, \alpha_{6}$, adalah koefisien untuk setiap faktor

Menurut Sugiyono (2005), untuk sampel jenuh yang menggunakan semua populasi untuk diteliti maka tidak perlu uji signifikansi. Selanjutnya Sudjana (2002) menjelaskan bahwa jika sampel yang diambil sebanyak populasi, maka data dianggap berdistribusi normal dan homogen.

\section{HASIL DAN PEMBAHASAN}

Hasil regresi linier berganda faktorfaktor yang mempengaruhi jumlah pembiayaan syariah melalui Rumah Pembiayaan Pertanian tersaji pada Tabel 2. Hasil regresi yang diperoleh menunjukkan bahwa nilai koefisien determinasi $\left(\mathrm{R}^{2}\right)$ didapat dari nilai $R$ squared pada tabel Model Summery hasil output dari uji regresi linier berganda menggunakan SPSS versi 25. Nilai koefisien determinasi $\left(\mathrm{R}^{2}\right)$ sebesar 0,517 atau sebesar 51,7 persen, artinya variabelvariabel independent yang dibangun dapat menjelaskan bahwa sebanyak 51,7 persen terjadi perubahan terhadap jumlah pembiayaan syariah melalui Rumah Pembiayaan Pertanain. Sebanyak 48,3 persen sisanya dijelaskan oleh faktorfaktor lain di luar model.

Tabel 2 . Hasil Pengolahan Data Regresi Linier Berganda

\begin{tabular}{lc}
\hline \multicolumn{1}{c}{ Variabel $^{\text {a }}$} & $\begin{array}{c}\text { Koefisien } \\
\text { Regresi }\end{array}$ \\
\hline (Constant) & 0,177 \\
Tanggungan Keluarga (X1) & 0,007 \\
Lama Menjadi Nasabah (X2) & 0,000 \\
Pengalaman Usaha (X3) & 0,067 \\
Pendapatan Usaha (X4) & $-0,217$ \\
Frekuensi Pembiayaan (X5) & 0,031 \\
Skala Usaha (X6) & 0,737 \\
Tahun Pendidikan (X7) & $-0,070$ \\
$R$ squared & 0,517 \\
\hline Keterangan: ${ }^{\text {a }) ~ N i l a i ~ s e l u r u h ~ v a r i a b e l ~ p a d a ~ m o d e l ~}$ \\
di Scalling \\
${ }^{*}$ ) signifikan pada taraf nyata 5\% \\
Sumber: Output SPSS data diolah (2020)
\end{tabular}

Kolom koefisien regresi dari setiap variabel bebas didapatkan hasil yang mempunyai nilai positif dan negatif, dimana yang bernilai positif memberikan pengaruh yang berbanding lurus dengan variabel terikatnya. Sementara, yang bernilai negatif menunjukkan pengaruh yang berbanding terbalik dengan variabel terikatnya.

Analisis hasil model regresi linier berganda dari masing-masing faktor jumlah pengambilan pembiayaan syariah diinterpretasikan sebagai berikut: 


\section{Tanggungan Keluarga (X1)}

Berdasarkan analisis pada Tabel 2 nilai koefisien regresi variabel tanggungan keluarga terhadap jumlah pembiayaan syariah yang diberikan adalah 0,007. Hal ini berarti setiap bertambahnya jumlah tanggungan keluarga petani sebanyak 1 persen, maka terjadinya peningkatan jumlah pembiayaan syariah yang disalurkan sebesar $0,7 \%$ dengan asumsi faktor lainnya tetap (ceteris paribus).

Nilai koefisien regresi variabel jumlah tanggungan keluarga yang bernilai positif, menunjukkan bahwa dengan bertambahnya jumlah tanggungan keluarga akan berpengaruh pada penambahan jumlah pembiayaan atau sebaliknya. Semakin bertambahnya jumlah tanggungan akan berdampak kepada semakin besarnya biaya kebutuhan keluarga. Hal ini sejalan dengan penelitian yang dilakukan oleh Aggriawan (2010) bahwa jumlah tanggungan keluarga bernilai positif mempengaruhi jumlah pembiayaan syariah yang diberikan.

Namun kenyataannya, anggota RPP yang memiliki jumlah tanggungan keluarga tergolong besar tidak menerima jumlah pembiayaan yang besar pula. Hal ini dibuktikan dari data di lapangan, bahwa petani yang memiliki jumlah tanggungan 6 orang hanya mendapatkan pembiayaan sebesar Rp 2.000.000 dan petani yang memiliki jumlah tanggungan 4 orang mendapatkan pembiayaan sebesar Rp 3.000.000.

Berdasarkan informasi yang diperoleh dari pihak RPP, dalam menentukan jumlah pembiayaan yang disalurkan kepada petani ditentukan oleh jumlah tanggungan keluarga. Tetapi, melihat sejauh mana kesanggupan petani untuk mengembalikan pembiayaan syariah yang disalurkan.

\section{Lama Menjadi Nasabah (X2)}

Berdasarkan analisis, nilai koefisien regresi variabel lama menjadi nasabah terhadap jumlah pembiayaan syariah yang diberikan adalah 0,000. Hal ini berarti, apabila pengalaman pembiayaan naik sebesar 1 persen, maka terjadi peningkatan jumlah pembiayaan syariah yang disalurkan sebesar $0,00 \%$ dengan asumsi faktor lainnya tetap (ceteris paribus). Artinya, pihak RPP tidak menjadikan variabel lama menjadi nasabah sebagai tolok ukur dalam memberikan pembiayaan.

Nilai koefisien regresi variabel lama menjadi nasabah bernilai positif, menunjukkan bahwa dengan semakin lamanya menjadi nasabah akan 


\section{FAKTOR-FAKTOR YANG MEMPENGARUHI JUMLAH PEMBIAYAAN SYARIAH \\ MELALUI PROGRAM RUMAH PEMBIAYAAN PERTANIAN \\ Deby Diana, Tuti Karyani}

berpengaruh terhadap penambahan jumlah pembiayaan atau sebaliknya. Penelitian ini bertolok belakang dengan penelitian yang dilakukan Oktavi (2009) yang menyatakan bahwa variabel lama menjadi nasabah bernilai negatif untuk mempengaruhi jumlah pembiayaan yang diberikan. Namun, sejalan dengan penelitian yang dilakukan Aryati (2006) yang menyatakan variabel lama menjadi nasabah bernilai positif mempengaruhi jumlah pembiayaan syariah yang diberikan.

Lama menjadi nasabah ternyata tidak menjadi tolok ukur dalam menentukan jumlah pembiayaan syariah. Menurut data lapangan didapatkan informasi bahwa petani yang sudah lama menjadi nasabah tetap mendapatkan pembiayaan yang sedikit. Bapak Lukman dan Ibu Nana yang sama-sama sudah menjadi anggota RPP selama 6 tahun mendapatkan jumlah pembiayaan yang berbeda yaitu sebesar Rp 1.000.000 dan Rp 2.000.000

Berdasarkan informasi dari pihak RPP menjelaskan bahwa pembiayaan syariah yang diberikan tergantung kepada riwayat pembiayaan yang dilakukan oleh petani. Apabila riwayat petani itu tidak ada permasalahan dalam peminjaman dan juga pengembalian serta adanya peningkatan usaha yang petani miliki, maka pihak RPP akan mempertimbangkan untuk memberikan pembiayaan yang lebih besar dari sebelumnya.

\section{Pengalaman Usaha (X3)}

Nilai koefisien regresi untuk variabel pengalaman usaha dilihat pada Tabel 2 bernilai sebesar 0,067 . Hal ini menunjukkan dengan bertambahnya pengalaman usaha sebesar 1 persen maka terjadi peningkatan jumlah pembiayaan syariah yang disalurkan sebesar $6,7 \%$ (ceteris paribus).

Variabel pendapatan usaha memiliki nilai koefisien regresi positif, maka semakin lama pengalaman berusahatani akan berpengaruh terhadap penambahan jumlah pembiayaan yang diberikan atau sebaliknya. Namun, penelitian ini tidak senada yang dilakukan oleh Barus (2009) dimana variabel pengalaman usaha bernilai negatif untuk mempengaruhi jumlah pembiayaan yang diberikan. Semakin lama mereka berusahatani maka akan semakin tahu mereka akan keadaan usahatani mereka.

Rata-rata nasabah/anggota RPP terjun ke bidang pertanian karena turun temurun dari keluarga mereka. Bahkan ada yang sudah mencapai 50 tahun 
mereka bekerja dalam bidang pertanian, sehingga mengetahui tentang bagaimana kondisi usaha mereka sendiri. Namun kenyataan di lapangan pengalaman usaha tidak menjadi tolok ukur dalam pengambilan pembiayaan. Petani yang sudah berpengalaman mencapai 50 tahun hanya mendapatkan pembiayaan sebesar $\mathrm{Rp}$ 1.000.000. Hal ini dikarenakan petani dalam melakukan pengambilan pembiayaan hanya sebagai penambah modal usaha.

\section{Pendapatan Usaha (X4)}

Berdasarkan hasil analisis pada Tabel 2 nilai koefisien untuk variabel pendapatan usaha sebesar -0,217 (bernilai negatif). Artinya, apabila pendapatan usaha yang diterima semakin besar maka jumlah pembiayaan yang diambil semakin sedikit. Pendapatan usaha dapat dijadikan indikator kemampuan dalam membayar pembiayaan yang telah diterima, karena semakin besar pendapatan usaha yang diperoleh akan berdampak pada semakin mudahnya kemampuan dalam mengembalikan pembiayaan syariah didapatkan. Hasil penelitian ini tidak senada dengan hasil penelitian oleh Anggriawan (2010) dan Barus (2009) yang menunjukkan bahwa variabel pendapatan usaha bernilai positif mempengaruhi jumlah pembiayaan.
Namun, hasil penelitian ini senada dengan Oktavi (2009) dimana hasil penelitiannya menunjukkan bahwa variabel pendapatan usaha bernilai negatif untuk mempengaruhi jumlah pembiayaan yang disalurkan.

Berdasarkan informasi yang didapatkan dari petani, jumlah pembiayaan yang disalurkan oleh RPP tidak melebihi dari pendapatan yang diterima oleh petani itu sendiri. Hal ini berhubungan dengan seberapa besar kesanggupan petani dalam mengembalikan pembiayaan yang disalurkan. Petani juga menjelaskan bahwa pihak RPP selalu melakukan perhitungan usaha dengan melihat adanya keseimbangan pendapatan dan juga pengeluaran sebelum melakukan kegiatan pembiayaan.

Sejalan dengan informasi yang diperoleh dari pihak RPP, dalam menyalurkan pembiayaan syariah pihak RPP melihat bagaimana kondisi usaha yang stabil dan normal pada usaha yang telah dijalankan oleh anggota RPP.

\section{Frekuensi Pembiayaan (X5)}

Berdasarkan analisis pada Tabel 2 nilai koefisien regresi variabel frekuensi pembiayaan terhadap jumlah pembiayaan syariah yang diberikan adalah 0,031 . Hal ini berarti setiap bertambahnya frekuensi 


\section{FAKTOR-FAKTOR YANG MEMPENGARUHI JUMLAH PEMBIAYAAN SYARIAH \\ MELALUI PROGRAM RUMAH PEMBIAYAAN PERTANIAN \\ Deby Diana, Tuti Karyani}

pembiayaan sebanyak 1 persen, maka terjadi peningkatan terhadap jumlah pembiayaan syariah yang disalurkan sebesar 3,1\% dengan asumsi faktor lainnya tetap (ceteris paribus).

Nilai koefisien regresi variabel frekuensi pembiayaan bernilai positif, berarti dengan meningkatnya frekuensi pembiayaan yang dilakukan akan berpengaruh pada penambahan jumlah pembiayaan. Namun, penelitian ini tidak sejalan dengan Aggriawan (2010) yang menunjukkan bahwa variabel frekuensi pembiayaan bernilai negatif untuk mempengaruhi jumlah pembiayaan yang diberikan.

Semakin sering melakukan pembiayaan akan berdampak kepada timbulnya kepercayaan antara nasabah/anggota dengan RPP. Timbulnya kepercayaan ini akan berpeluang terhadap semakin besarnya pembiayaan yang didapatkan dari pembiayaan sebelumnya. Walaupun demikian, frekuensi pembiayaan tidak menjadi tolok ukur dalam mempengaruhi jumlah pembiayaan syariah yang diambil. Petani yang sudah sering melakukan kegiatan pembiayaan ternyata tidak mendapatkan pembiayaan yang relatif lebih tinggi. Sebagai contoh, Ibu Yuhaeti yang baru sekali menerima pembiayaan dari RPP mendapatkan bantuan modal sebesar Rp 2.000.000, sedangkan Ibu Rima yang sudah 4 kali menerima bantuan modal hanya mendapkan bantuan modal sebesar Rp 1.100.000.

Berdasarkan informasi dari pihak RPP memang semakin sering petani melakukan pembiayaan akan berdampak kepada timbulnya kepercayaan. Namun, pihak RPP tentu akan mempertimbangkan jumlah pembiayaan yang akan disalurkan kepada petani RPP. Apabila petani mengajukan pembiayaan yang dirasa tidak rasional, maka pihak RPP akan meninjau ulang terhadap analisis potensi usaha petani tersebut. Hal tersebut dilakukan untuk mencegah terjadinya penyelewengan dana yang diberikan oleh pihak RPP, karena dana yang diperoleh oleh RPP merupakan dana yang diamanahkan untuk disalurkan kepada nasabah yang memerlukan tambahan pembiayaan untuk usahataninya.

\section{Skala Usaha (X6)}

Tabel 2 menunjukkan bahwa nilai koefisien regresi variabel skala usaha terhadap jumlah pembiayaan syariah yang disalurkan adalah 0,737. Hal ini berarti setiap bertambahnya skala usaha sebanyak 1 persen, maka terjadi peningkatan terhadap jumlah pembiayaan 
syariah yang disalurkan sebesar $73,7 \%$ (ceteris paribus).

Nilai koefisien regresi variabel skala usaha bernilai positif, menunjukkan bahwa dengan meningkatnya skala usaha akan berpengaruh terhadap peningkatan jumlah pembiayaan yang disalurkan atau sebaliknya. Penelitian ini tidak sejalan dengan Anggriawan (2010) dimana hasil penelitian menunjukkan bahwa variabel skala usaha bernilai negatif untuk jumlah pengambilan pembiayaan. Namun, penelitian ini sejalan dengan Aryati (2006) dan Barus (2009) yang menyatakan bahwa variabel skala usaha bernilai positif terhadap jumlah pengambilan pembiayaan.

Berdasarkan data di lapangan diperoleh informasi bahwa pembiayaan yang diberikan tidak akan lebih dari modal yang petani butuhkan. Petani menjelaskan bahwa dalam mengajukan pembiayaan pihak RPP selalu melakukan analisis kesanggupan usahatani nasabah/anggota. Hal ini dilakukan agar pengembalian dana yang disalurkan tidak dirasa memberatkan petani. Sebagian dana yang diperoleh oleh petani digunakan sebagai tambahan modal untuk melanjutkan usaha mereka.

Semakin besar skala usaha maka semakin besar pula modal yang diperlukan. Pihak RPP selalu menyelaraskan antara modal dengan pembiayaan yang diberikan untuk nasabah/anggota. Apabila pembiayaan yang diberikan melalui RPP lebih besar daripada modal yang dibutuhkan untuk usahatani dikhawatirkan nasabah/anggota tidak sanggup untuk membayar kembali pembiayaan yang telah diberikan. Oleh karena itu, pihak RPP tidak akan memberikan pembiayaan lebih dari modal yang diperlukan.

\section{Tahun Pendidikan (X7)}

Variabel tahun pendidikan jika dilihat pada Tabel 2 didapatkan bahwa nilai koefisien regresi untuk jumlah pembiayaan syariah yang diberikan bernilai negatif, yaitu sebesar $-0,070$. Dapat diartikan bahwa semkain tinggi tahun pendidikan tidak akan mempengaruhi dengan besarnya jumlah pengambilan yang disalurkan. Penelitian ini tidak sejalan dengan Anggriawan (2010) dimana hasil penelitian menunjukkan bahwa variabel tahun pendidikan bernilai positif mempengaruhi jumlah pembiayaan yang diberikan. Namun, penelitian sejalan dengan penelitian Oktavi (2009) dimana variabel tahun pendidikan bernilai negatif mempengaruhi jumlah pembiayaan yang diberikan. 
Semakin tinggi tingkat pendidikan maka akan semakin besar pula pembiayaan yang diberikan. Kenyataannya tingkat pendidikan tidak dijadikan tolok ukur dalam menentukan jumlah pembiayaan. Mayoritas petani yang tergabung dalam RPP memiliki tingkat pendidikan SD (61,1\%). Oleh karena itu, pengetahuan dan keterampilan yang dimiliki oleh petani tidak berkaitan dengan penentuan besar atau kecilnya pembiayaan yang diberikan. Hal ini tentu selaras dengan informasi yang diperoleh dari pihak RPP, karena menurut pihak RPP yang terpenting adalah ketekunan seseorang tersebut untuk menjalani usahanya. Jumlah pendidikan juga tidak menentukan skill yang dimiliki oleh seseorang.

\section{KESIMPULAN DAN SARAN}

\section{Kesimpulan}

Berdasarkan hasil penelitian dan pembahasan yang telah dilakukan, maka diperoleh kesimpulan sebagai berikut:

1. Faktor-faktor yang berbanding lurus mempengaruhi jumlah pembiayaan syariah melalui RPP adalah tanggungan keluarga, lama menjadi nasabah, pengalaman usaha, frekuensi pembiayaan dan skala usaha.
2. Faktor-faktor yang berbanding terbalik mempengaruhi jumlah pengambilan pembiayaan melalui RPP adalah pendapatan usaha dan tahun pendidikan.

\section{Saran}

Saran untuk penelitian ini adalah pihak RPP perlu menambahkan proporsi pembiayaan syariah yang diberikan, karena dapat menjadi daya tarik bagi petani-petani lain untuk bergabung ke Rumah Pembiayaan Pertanian, sehingga pembiayaan yang disalurkan melalui RPP dapat menjadi alternatif pembiayaan di Kecamatan Pacet.

\section{DAFTAR PUSTAKA}

Anggriawan, A. (2010). Analisis Efektivitas dan Faktor-Faktor yang Mempengaruhi Realisasi Pembiayaan Syariah pada Sektor Agribisnis (Studi Kasus : PT. BPRS Amanah Ummah, Bogor). [Skripsi]. Fakultas Ekonomi dan Manajemen, Institut Pertanian Bogor.

Anjani S.S. (2013). Analisis Efektivitas Pembiayaan Syariah Bagi Sektor Pertanian pada KBMT Ibaadurrahman, Ciawi, Bogor. [Skripsi]. Bogor: Fakultas Ekonomi dan Manajemen, Institut Pertanian Bogor.

Aryati. (2006). Analisis Permintaan dan Efektivitas Pembiayaan Usaha Kecil pada Lembaga Keuangan Mikro Syariah (Studi Kasus KBMT Khidmatul Ummah, Kecamatan Cibungbulang, Bogor) . [Skripsi]. 
Bogor: Fakultas Ekonomi dan Manajemen, Institut Pertanian Bogor.

Badan Pusat Statistik. (2019). Keadaan Ketenagakerjaan Indonesia Tahun 2018. Jakarta: Badan Pusat Statistik.

. (2019). Produk Domestik Bruto Indonesia Triwulan 2014 - 2018. Jakarta: Badan Pusat Statistik.

Barus, A.N. (2009). Analisis FaktorFaktor Pengambilan Pembiayaan dan Penilaian Efektivitas Pembiayaan Syariah Bagi Usaha Kecil pada BMT Dana Insani Kabupaten Gunung Kidul Propinsi Yogyakarta. [Skripsi]. Bogor: Fakultas Pertanian, Institut

Oktavia, S.K. (2009). Analisis FaktorFaktor yang Mempengaruhi Pengambilan Pembiayaan dan Efektivitas Pembiayaan Usaha Kecil pada Lembaga Keuangan Mikro Syariah (Studi Kasus: KJKS BMT Bina Umat Sejahtera, Lasem, Jawa Tengah). [Skripsi]. Bogor: Fakultas Ekonomi dan Manajemen, Institut Pertanian Bogor.
Otoritas Jasa Keuangan. (2019). Statistik Perbankan Syariah Oktober 2019. Otoritas Jasa Keuangan

Robinson, M. (2000). The Microfinance Revolution. Institut Fellow Emeritus, Washington DC.

Sudjana. (2002). Metode Statistik. Jakarta: Tasito.

Sugiyono. (2005). Metode penelitian Bisnis. Bandung: Alfabeta.

Sugiyono. (2016). Metode Penelitian \& Pengembangan: Research and Development.

Sugiyono. (2017). Metode Penelitian Pendidikan (Pendekatan Kuantitatif, Kualitatif, dan R\&D). Bandung: Anggota Ikatan Penerbit Indonesia (IKAPI).

Widiana, dkk. (2017). Menilik Urgensi Penerapan Pembiayaan Akad Salam pada Bidang Pertanian di Lembaga Keuanagan Syariah di Indonesia. Jurnal Ekonomi dan Perbankan Syariah. 